Кирилюк Н. А., кандидат політичних наук, доцент кафедри докулентознавства та інфбормаційної діяльності Державного університету телекомунікаиій

\title{
ІСНУВАННЯ ЛІБЕРАЛЬНОЇ ДЕМОКРАТІЇ ТА МОЖЛИВОСТІ ЇЇ РЕАЛІЗАЦІЇ В УКРАЇНІ
}

\begin{abstract}
Анотація. На початку XXI століття прихильники ліберальної демократії все більше звертаються до пошуку підтвердження іiї легітимності. Водночас усе більше держав, які іiї критикують, не можуть запропонувати послідовну альтернативу. У статті розглянуто специфіку прояву ліберальної демократії, проаналізовані можливості її реалізації за сучасних українських реалій. Розглянута ретроспектива розвитку ліберальної демократії в Україні. Визначено, що сьогодні, коли відбувся процес трансформації всіх ідеологій, зокрема і ліберальної, проблема ії зіставлення з демократією актуалізується і набуває нових рис. У сучасній науці існують різноманітні підходи до визначення змісту та чинників демократизації. Але найбільш поширеною і дієздатною, що не тільки в теорії, але й на практиці проявила себе, постала ліберальна демократія. Сучасний лібералізм в Україні проголошує, що держава повинна відповідати за забезпечення таких умов добробуту, як здоров'я, наявність житла, пенсії й освіти, а також, якщо не управляти, то регулювати економіку. Дехто вважає, що лібералізм $є$ непослідовною ідеологією, яка має суперечки щодо бажаного ставлення і ролі держави. Складність реалізації ліберальної демократії в Україні полягає в аморфності членів суспільства до усвідомленої громадянської діяльності, унаслідок тривалої апатії до суспільно-політичних процесів та відсутності необхідних базових знань, що надають можливість свідомо брати участь у тих чи інших політичних діях. Окрім цього, майже відсутне почуття особистої відповідальності й ініціативи, як відсутні ідеали та цінності. Інколи занадто надмірно поставлене національне питання в політиці, коли націоналізм використовується як своєрідний засіб маніпулювання масами. Існує схильність громадян суспільства до державного патерналізму, світоглядний вакуум майже унеможливлює ставлення принципів лібералізму, ліберальної демократії зокрема. Демократичний режим потребує плюралізму. Без нього багатоманітність сил, які ведуть протиборство та намагаються віднайти загальне благо, закріпити ідентичність спільноти та політичну артикуляцію загалом, стає неможливою. Справжні демократичні цінності потребують рівності громадян; гідної освіти, що наддасть можливість свідомо брати участь у виборчому процесі; незалежної судової влади, що контролюватиме виборчий механізм; підкорення адміністрації політичній владі, щоб унеможливити трансформацію демократії в олігархію; легітимності влади. Розвиток недемократичних правопорядків, гіпертрофія індивідуалістської концепції прав людини та поси-
\end{abstract}

лення обмежень демократичної політичної влади суттєво послаблюють демократію.

Ключові слова: ліберальна демократія, лібералізм, демократія, демократична держава.

Постановка проблеми. Демократія - глобалізаційний процес політичного розвитку: «<...> демократія успішно глобалізується. 31985 по 2000 рік частка населення світу, що мешкають у «найдемократичніших» державах, збільшилася із 38 до 57\%» [9]. Відомий американський дослідник С. Хантінгтон характеризує цей процес як третю хвилю демократизації у світі та зазначає, що на початку 90-х рр. «демократія виступає як єдина легітимна та життєздатна альтернатива авторитарному режиму будь-якого типу» [7]. Однак більш доречною і гостро актуальною сьогодні є думка Ф. Фукуями: «Для спільнот, різко розколотих на соціальні класи, національні і релігійні групи, демократія може виявитися формулою безсилля та застою $<\ldots>$ Модернізуючи диктатури можуть виявитися набагато ефективнішими за демократій у створенні соціальних умов, що допускають капіталістичне економічне зростання, а із часом і виникнення стабільної демократії» [5, с. 192-193]. Якщо говорити про слабкі місця демократії, то це радше слабкі місця економічної складової частини, ніж політичної чи соціальної.

На початку XXI ст. прихильники ліберальної демократії все більше звертаються до пошуку підтвердження іï легітимності. Водночас усе більше держав, які ㄲï критикують, не можуть запропонувати послідовної альтернативи. Сучасна демократія в Україні та світі загалом нагадує викривлене дзеркало. Часто демократією називають зовсім недемократичні речі. Маємо можливість поглянути на ретроспективу розвитку ліберальної демократії в Україні крізь призму національних ідей і визначити можливості запровадження ліберальної демократії в сучасному українському суспільстві, ураховуючи дослідження світових класиків та сучасників теорії демократії.

Аналіз останніх досліджень і публікацій. Для написання роботи було проаналізовано праці Дж. Мілля, Ю. Хабермаса, С. Рінгена, Ш. Муфф, Д. Хелда, К. Шмітта, Ф. Фукуями. Також зазначимо, що у джерел формування напряму стояли такі відомі постаті, як I. Бентам, Б. Констан, I. Берлін, К. Поппер, Дж. Сарторі, Ал. де Токвіль,С. де Мадарьяга, Р. Дарендорф, Р. Арон, Ф. Гайєк, А. Лейпхарт, Р. Даль, Л. Даймонд та інші. Прихильниками ліберальної демократії можна вважати таких класиків 
української політичної думки: М. Драгоманова, М. Павлика, I. Франка, Б. Кістяківського, М. Турган-Барановського, В. Вернадського. Серед сучасних українських дослідників ідеї демократичного лібералізму знайшли місце в роботах М. Жулинського, О. Стогової, О. Долженкової, І. Головка й інших.

Мета статті - дослідження ідей демократичного лібералізму як природного напряму розвитку українського суспільства, окреслення можливих перспектив оновлення, перетворення.

Виклад основного матеріалу дослідження. Сьогодні, коли відбувся процес трансформації всіх ідеологій, зокрема і ліберальної, проблема ії зіставлення з демократією актуалізується і набуває нових рис. У сучасній науці існують різноманітні підходи до визначення змісту та чинників демократизації. Але найбільш поширеною і дієздатною, що не тільки в теорії, але й на практиці проявила себе, постала ліберальна демократія. «Лібералізм породжує демократію і нестримно робить перехід у демократизм. Такий його послідовний розвиток» [1].

Лібералізм випробуваний часом i знайшов своє місце в багатьох державах. У таких країнах, як Іспанія, Естонія, Словенія, Кіпр, Канада, Тайвань, Уругвай, Фінляндія, цінності лібералізму відіграють важливу роль у формуванні нових цілей суспільства, незважаючи на те, що реальне іноді не збігається 3 ідельним.

Ліберальна демократія не передбачас безумовного дотримання всіх аспектів класичної ліберальної ідеології, але непорушним залишається той факт, що вона забезпечує кожній людині захист від свавілля влади й органів правопорядку. Таке розуміння «ліберальності» було відтворене ще за доби буржуазної революції у XVIII ст. Правова держава як форма суспільно-політичного ладу через обраних представників повинна здійснювати владу заради захисту прав громадян, дотримуватись відповідних правових процедур, права на приватну власність, свободу слова, свободу зібрань, свободу віросповідання та недоторканності особистого життя. На відміну від Західної Європи, де ліберальні ідеї в XIX ст. «тріумфально простували», що засвідчує М. Драгоманов, лібералізм в Україні не мав успішного поширення і не набув остаточного оформлення. Звичайно, здебільшого це пов'язано з панівним політичним режимом, що жорстоко пригнічував будь-які прояви визвольного руху, як наслідок - засилля радикальних течій. «Відкрите суспільство» - необхідна складова частина ліберальної демократії, що характеризується виваженістю, плюралізмом, єдністю існування і конкуренцією найширшого спектра суспільно-політичних поглядів. Модель відкритого суспільства передбачає гнучку реакцію на суспільні запити й унеможливлює консервацію влади панівною елітою, водночас гарантує можливість зміни влади та створює різноманітні стимули.

Історично доведено, що лібералізм в Україні підпорядкований соціальним і національним ідеям. I незважаючи на оптимізм, з яким ліберальна демократія дивиться в майбутнє, у повсякденних реаліях відчуваємо недовіру до того, що взагалі стосується слів «політика», «демократія», «лібералізм». Отже, Україна $є$ демократичною державою, але утримання такої форми стикається з низкою складнощів. Найбільш явні: аморфність членів суспільства до усвідомленої громадянської діяльності внаслідок тривалої апатії до суспільно-політичних процесів і відсутності необхідних базових знань, що надають можливість свідомо брати участь у тих чи інших політичних діях; майже відсутнє почуття особистої відповідальності й ініціативи; відсутність ідеалів та цінностей; націоналізм використовується як своєрідний засіб маніпулювання масами; схильність громадян суспільства до державного патерналізму, світоглядний вакуум майже унеможливлюе ставлення принципів лібералізму, ліберальної демократії зокрема.

«Якісна» демократія потребує: рівності громадян, які формують виборчий процес; надання такого рівня освіти, щоб мати можливість компетентно брати участь в ухваленні політичних рішень; досконалої судової влади (наскільки це можливо), що здатна незалежно контролювати виборчий механізм і відповідальність представників перед людьми; підкорення адміністрації політичній владі, щоб унеможливити трансформацію демократії в олігархію; легітимності влади, тобто легітимно обрана влада повинна бути наділена можливостями ухвалення і здійснення необхідних рішень.

Відповідно, розвиток недемократичних правопорядків, гіпертрофія індивідуалістської концепції прав людини та посилення обмежень демократичної політичної влади суттєво послаблюють демократію.

Але недоліки подекуди можна розглянути як переваги. Ф. Фукуяма стверджував: «Лібералізм як світоглядна і політична концепція приречений на перемогу» $[5$, с. 81]. Якщо людство зараз формує гуманітарний світогляд, в основі якого ліберально-демократичні цінності, нам неминуче доведеться адаптуватися до нових стандартів. На глобальному просторі панування різноманітності рівних можливостей наша присутність і взаємодія з іншими спільнотами можлива за умови забезпечення в українському соціумі індивідуальних свобод і цінностей та солідарної відповідальності за непорушення цих свобод, за їх збереження. Під час аналізу поширення ліберальних ідей в Україні можна визначити такі етапи: 1) М. Драгоманов (сер. XIX ст.) і його прагнення об'єднати західні ліберальні ідеї із соціальними і національними; 2) діяльність науково-культурної інтелігенції, представників російської ліберальної течії в Україні (кін. XIX - поч. XX ст.) (Б. Кістяківський, М. Туган-Барановський, В. Вернадський); 3) рух українських дисидентів, що проявився як правозахисна діяльність у програмних документах Української групи Хельсінки. Це підняло питання про порушення прав і свобод особи в Радянському Союзі та політичну незалежність України (В. Чорновіл, Е. Сверстюк, В. Стус та ін.).

Ліберальний напрям в українській суспільній думці з'явився у другій половині XIX ст. М. Драгоманов виклав своє розуміння моделі нової української держави в листі до I. Франка: «Принципи сучасної всесвітньої цивілізації найбільш відповідні постулатові: лібералізм у його найпослідовнішій формі, федералізм - у справах державних, демократизм - у справах соціальних $з$ найтвердішою гарантією - асоціацією у справах економічних, раціоналізм - у справах письменницьких, наукових» [3]. М. Драгоманов наполягав на необхідності пов'язати український національний рух та його програму з європейськими ліберально-демократичними концепціями. Він писав, що українці багато втратили, бо коли народи Європи створювали свої держави, нам це не вдалося. Завдання кожної людини і народу - пізнавати себе і прагнути йти до цивілізації водночас і разом із цивілізацією. Але відтворення індивідуальної свободи вимагає самопізнання та високої національної самосвідомості. На жаль, рівень цивілізованості народу настільки низький, що не дозволяє йому цього досягти. М. Драгоманов стверджував, 
що лібералізм є доктриною, відповідно до якої людська індивідуальність $є$ вищою цінністю. Політично це проявляється в розширенні та зміцненні індивідуальних прав, отже, й індивідуальних свобод, що не повинні бути обмежені державною владою. Недоторканність особистої сфери важливіша за участь у створенні, формуванні колективної політичної волі, а індивід iз його волею є основою всіх можливих соціальних порядків.

Із часом протоліберальні ідеї М. Драгоманова перейняли I. Франко, Б. Кістяківський, М. Павлик. Серед основних ідей можна зазначити такі: існування демократичної держави можливе лише за умови політичної свободи; людина - найвища та головна цінність суспільства, незалежно від статусу; приватна власність $є$ центральною в системі політико-економічних категорій; верховенство права посідає важливе місце в суспільному житті; загальнолюдські цінності мають пріоритет над соціально-класовими чи національними; базові цінності демократії - це децентралізація держави та місцеве самоврядування; етичні засади завжди повинні супроводжувати політичну діяльність.

У збірнику «Вехи» друкувалася критика більшовицької ідеології та публікувалися нові погляди лібералізму. Серед громадських діячів - прихильників лібералізму варто зазначити Б. Кістяківського. Свою наукову діяльність він присвятив пошуку співвідношення соціальної та ліберальної ідей. Стаття «Російська соціологічна школа та категорія можливості» остаточно визначила позиції Б. Кістяківського як послідовника М. Драгоманова і прихильника лібералізму. У роботі «Держава правова та соціалістична» зазначена необхідність поєднання соціальної ідеї з ліберальною, де право розглядається в контексті соціальних наук і обгрунтовується розуміння філософських засад правової держави. Дослідження українських діячів переплітаються з поглядами Ш. Муфф і К. Шмітта щодо соціальних цінностей, національної ідеї, ліберальної демократії загалом.

Ш. Муфф убачає у природі демократії парадокс, що виникає як наслідок того, що центральним поняттям у демократії є «народ», і тоді логічним є зв'язок з ідеєю національної держави. Лібералізм передбачає ідею абстрактного індивіда, що є носієм «людської природи», отже, проголошує рівність усіх людей. Однак, незважаючи на це, Ш. Муфф, прибічниця «лівого» проєкту демократії, усе ж погоджується із протилежним ставленням К. Шмітта щодо аналізу таких питань, як кордони громадянства і природа ліберально-демократичного консенсусу. Логіка демократії, за Ш. Муфф, неминуче передбачає час замикання, що потребує сам процес утворення «народу», «нації». I цього неможливо уникнути в жодній моделі демократії. Незважаючи на те, що логіки демократії та лібералізму різняться, їх поєднана артикуляція може давати позитивні результати. Демократична політика - «<.. > це не та, за якою народ, який остаточно встановився, здійснює власне правління. Момент правління нерозривно пов' язаний з безпосередньою боротьбою за визначення народу та встановлення його ідентичності. Однак така ідентичність ніколи не може бути остаточно встановлена <...> Ліберальна демократія означає визнання цього розриву між народом $\mathrm{i}$ його різноманітними ідентифікаціями. Тому важливо зберігати простір суперництва відкритим $<$...>» [4].

Власне розуміння ліберальної демократії пропонували також фундатори Української академії наук М. Туган-Барановський, В. Вернадський, які значно сприяли поширенню лібералізму в Україні. М. Туган-Барановський вірив у здатність науки розв'язувати соціальні проблеми (стаття «Вплив ідей політичної економії на природознавство та філософію»). Досить суттєвим було й обгрунтування важливості ролі приватної власності в системі економічних відносин: «Сучасне людство не може обійтися без цього стимулу господарської енергії < ..> Тому повне припинення дії приватно-господарської системи було 6 рівнозначне економічному, культурному і взагалі соціальному занепадові» [2]. М. Туган-Барановський спробував проаналузвати проблему вагомості ролі особистості в політекономічному контексті. «Інтереси різних суспільних класів різні, i, стоячи на точці зору кожного з цих суспільних інтересів, доводиться висувати на перший план різні завдання теоретичного дослідження. Але $є$ можливість піднестися над цією відмінністю інтересів, знайти таку точку зору, з якої практичні висновки науки повинні бути обов'язкові і для всіх суспільних груп, незалежно від їх приватних інтересів» [2]. Таким визначальним принципом вчений вважав людську особистість - основний важіль ліберальної ідеології. «Центральною ідеєю сучасної свідомості є ідея верховної цінності <..> Будь-яка особистість є верховна мета в собі, через що всі люди рівні, як носії святині людської особистості. Це і визначає верховний практичний інтерес, з точки зору якого може бути побудована єдина політична економія: інтерес не робітника, капіталіста або землевласника, а людини взагалі, незалежно від приналежності їі до того чи іншого класу» [2]. Вчення В. Вернадського також обгрунтовувало опір будь-якому насильству над особистістю. Він уважав соціалізм тією ідеологією, яка не дає вільно розвиватися особистості. За духом міркування В. Вернадського споріднені з ліберальними філософсько-економічними поглядами Ф. Гайєка: «Суперечка про ринковий порядок і соціалізм є суперечкою про виживання - не більше, а ні менше» [6, с. 114]. Залишившись прибічником соціалістичної моралі, українське суспільство втратило б більшу частину населення, а решта, що залишилась, перебувала б у зубожінні. Історія політичної думки в Україні крізь призму ліберальних ідей має глибоке коріння. Не варто нехтувати ідеями лібералізму, хоча б тому, що жодна інша ідея не знайшла свого постійного місця в сучасному українському суспільстві. Також, якщо поглянути на основних представників, М. Драгоманова, Б. Кістяківського, М. Туган-Барановського, В. Вернацького та багатьох інших, тих, хто обстоював ліберальні ідеї, зрозумілими стають їхня сила і віра у свободу, права людини, гідність людської особистості.

Висновки. Хибою українського лібералізму минулої доби була недооцінка національного в системі світоглядних засад суспільства та ролі держави у співвідношенні з іншими суспільно-політичними інститутами. Ключове місце відводилося концепції демократії, особливо певним принципам прямої демократії в організації державної влади, регіонального та місцевого самоврядування. Програмні ідеї лібералів здавалися нереальними для українських земель у складі імперських держав із тоталітарним політичним режимом. Ці ідеї в Україні завжди сприймалися як утопія, ніколи не мали широкої підтримки. Проблема сучасного українського лібералізму полягає у використанні морально і політично застарілих концепцій класичного лібералізму. Для України характерний «синдром імплантування політичних систем». Певна частина демократичних сил України, що зорієнтована на ліберальні моделі західного світу, 
свідомо чи вимушено копіює світоглядні засади цих країн. Застарілі погляди та викривлені ідеї ускладнюють процес, «ідеологія занадто зрощена з цим поверховим просвітництвом і в ньому потанули блискавки більш високої правди» [1]. Сучасний лібералізмв Україні проголошує, що держава повинна відповідати за забезпечення таких умов добробуту, як здоров'я, наявність житла, пенсії та освіти, а також, якщо не управляти, то регулювати економіку. Дехто вважає, що лібералізм $є$ непослідовною ідеологією, яка має суперечки щодо бажаного ставлення і ролі держави. 3 кінця XX ст. лібералізм також стояв віч-на-віч перед викликом зростаючої моральної та культурної строкатості на Заході, підйомом релігійного фундаменталізму й інших політичний віровчень, які не згодні з головними ліберальними принципами. Як наслідок, ліберали деколи надавали іншої форми своїм ідеям і цінностям, а в екстремальних випадках навіть ставили під сумнів, чи лібералізм прийнятний для всіх суспільств. На заваді становлення ліберальної демократії стоїть як відсутність правової моделі політичних інститутів, так i «криза на рівні ідей» тобто «<..> ключовою слабкістю, що, у решті-решт, обрушилася на (від авт. - Україна та інш. - Н. Д.) сильні держави, була неспроможність до легітимності» [5, с. 47]. Демократичний режим потребує плюралізму. Без нього багатоманітність сил, які ведуть протиборство та намагаються віднайти загальне благо, закріпити ідентичність спільноти, - політична артикуляція неможлива. «Кризи - близнюки авторитаризму і соціалістичного централізованого планування залишили на рингу змагань потенційно універсальних ідеологій тільки одного учасника: ліберальну демократію, вчення про особистісну свободу і суверенітет народу. Ї̈̈ сприймають усе більше число держав, водночас іiі критики не можуть запропонувати послідовної альтернативи» [5, с. 84-85].

\section{Jimepamypa:}

1. Бердяев Н. Философия неравенства. Собрание сочинений / H. Бердяев. T. IV. Париж : YMCA-Press, 1990. C. 417-461. URL: http://yakov.works/library/02_b/berdyaev/1918_20_01.html.

2. Горкін Л. Михайло Туган-Барановський - мислитель, вчений, громадянин. Політична економія / М. Туган-Барановський. Київ : Наукова думка, 1994. С. 21.

3. Драгоманов М. Листи до Івана Франка. Варшава, 1937. Т. 1. С. 83.

4. Муфф Ш. Карл Шмитт и парадокс либеральной демократии. Логос. 2004. № 69450. С. 140-153. URL: http://www.ruthenia.ru/ logos/number/45/12.pdf.

5. Фукуяма Ф. Конец истории и последний человек. Пер. с англ. М. Левина. Москва : А.С.T., 2007. 592 с. URL: http://yanko.lib.ru/ books/politologiya/fukuyama=the_end_of_history\&the_last_ man=ann.htm.

6. Хайек Ф. Пагубная самонадеянность. Ошибки социализма. Москва : Новости ; Catallaxy, 1992. 304 c. URL: https://knigogid.ru/ books/7361-pagubnaya-samonadeyannost/toread.

7. Хантингтон С. Третья волна: Демократизация в конце XX века. Москва : РОССПЭН, 2003. С. 16-17. URL: https://studfile.net/ preview/3829746/
8. Шварцмантель Д. Идеология и политика. Москва : Гуманитарный центр, 2009. $312 \mathrm{c}$.

9. UNDP, Human Development Report 2002. United Nations Development Program. New York : Oxford University Press, 2002. P. 15.

Dubovyk N., Kyryliuk N. Existence of liberal democracy and possibilities of its implementation in Ukraine

Summary. At the beginning of the 21 st century, supporters of liberal democracy increasingly turn to seek for confirmation of its legitimacy. However, an increasing number of states that criticize it are unable to offer a coherent alternative. The article addresses the specificity of liberal democracy manifestation and analyses the possibilities of its realization in the contemporary Ukrainian reality. Also the article addresses the issue of retrospective of liberal democracy development in Ukraine. It is determined that today, when the process of transformation of all ideologies, including the liberal one, has taken place, the problem of its juxtaposition with democracy is actualizing and acquiring new features. In modern science, there are various approaches to determining the content and factors of democratization. But liberal democracy is marked as the most widespread and viable, not only in theory but also in practice. Modern liberalism in Ukraine proclaims that the state must be responsible for ensuring welfare conditions such as health, housing, pensions and education and, if not governed, to regulate the economy. Some believe that liberalism is an inconsistent ideology that has controversy over the desirable attitude and role of the state. The complexity of the implementation of liberal democracy in Ukraine lies in the amorphousness of members of the public to conscious civic activity, due to the continued apathy for socio-political processes and the lack of the necessary basic knowledge that enable one to participate deliberately in certain political activities. In addition, there is almost no sense of personal responsibility and initiative, as there are no ideals and values. Sometimes a national question is posed beyond measure in politics when nationalism is used as a kind of mass manipulation tool. There is a tendency of society citizens for state paternalism, and a worldview vacuum makes it almost impossible to treat the principles of liberalism and liberal democracy in particular. The democratic regime needs pluralism. Without it, the multiplicity of forces that are fighting and trying to find the common good, to consolidate community identity and political articulation in general, becomes impossible. True democratic values need equality of citizens; decent education that will enable them to participate deliberately in the electoral process; independent judiciary that will control the electoral mechanism; subjugation of the administration to political power to prevent the transformation of democracy into an oligarchy; legitimacy of power. Development of undemocratic rule of law, hypertrophy of the individualist concept of human rights, and strengthening of restrictions on democratic political power significantly weaken democracy.

Key words: liberal democracy, liberalism, democracy, democracy state. 